\title{
Academic Performance of Pre-Graduate Students
}

\author{
Hazilah Mohd Amin ${ }^{1}$, Siti Aishah Hanawi ${ }^{1}$, Hazura Mohamed ${ }^{1}$, Saidah Saad ${ }^{1}$, Noraidah Sahari ${ }^{1} \&$ Ibrahim \\ Mohamed $^{1}$ \\ ${ }^{1}$ Faculty of Information Science and Technology, Universiti Kebangsaan Malaysia, Selangor, Malaysia \\ Correspondence: Hazilah Mohd Amin, Faculty of Information Science and Technology, Universiti Kebangsaan \\ Malaysia, 43600 UKM Bangi, Selangor, Malaysia. Tel: 60-389-216-728. E-mail: hma@ftsm.ukm.my
}

Received: February 7, 2013 Accepted: November 30, 2012 Online Published: May 24, 2013

doi:10.5539/ies.v6n6p131

URL: http://dx.doi.org/10.5539/ies.v6n6p131

\begin{abstract}
This study aims to investigate the performance of FTSM students' academic achievement, based on the number of years of their study and entry requirements. The main objectives of this study are to look at the STPM, Matriculation and Diploma students' academic achievement while studying in IHE, and whether students with low-entrance CGPAs could compete in IHE. Data were analyzed using the descriptive statistics and statistical inference; ANOVA. The findings of this study show that students with low-entrance CGPAs could still obtain the equivalent CGPAs as the high-entrance CGPA students while in IHE. STPM students have managed to improve their CGPAs in IHE. Matriculation students with low CGPA managed to improve their performance, while those with excellent CGPAs were able to maintain theirs. The results found that only Diploma holders have shown a decrease in their FTSM CGPAs compared with their entrance CGPAs. The results of this study may be able to enhance the motivation of students with poor entrance CGPAs, and also to motivate lecturers to continue guiding students with low entrance CGPAs.
\end{abstract}

Keywords: academic achievement, CGPA, STPM, matriculation, diploma

\section{Introduction}

Education is the driving force of a nation's economic development. Students' potential can be polished and enhanced if they work hard, be responsible and have strong commitment to learn with proper guidance from dedicated academic staff (Norhani et al., 2005). According to Hall and Lindzey (in Abdul Hamid et al., 1999), psychologists agree that individuals 'may' and could excel in all aspects of life if they are properly guided.

Numerous studies have been carried out in search of factors affecting students' academic performance. Zuaini et al. (2008), Todd (2001), Adamson and Clifford (2000) and Alexander et al. (2003) have found that a student's pre-university academic performance is not able to predict her academic performance at the university. Studies done in educational institutions in Malaysia by Hafizah et al. (2011) found no dependencies between entrances CGPA with CGPA in JKEES, UKM. She also found that $3^{\text {rd }}$ and $4^{\text {th }}$ year students have higher CGPAs compared with $2^{\text {nd }}$ and $1^{\text {st }}$ year students. In addition, she found that the mean entrance CGPA in JKEES has declined.

Among the entrance requirements to the Institution of Higher Education (IHE) is to have excellent results in Malaysian Higher Education Certificate (STPM), Matriculation or Diploma. The syllabus for both the Matriculation and STPM are almost the same. However, the STPM syllabus is more detailed and in-depth than the Matriculation. This is because, the study period for STPM is two years compared to only one year for matriculation. Apart from that, majority of the Matriculation students are Bumiputera while majority of STPM students are Chinese.

The distribution and allocation of students to all of the universities in Malaysia, except for USM, is through the UPU system. The method used is that $90 \%$ is based on merit, while another $10 \%$ is based on co-curriculum. The UPU system enables students to fill out only a single form which is submitted through the UPU, instead of having to fill out an application form for each university. The universities however, do not have the autonomy to choose their students. This is because, students who are accepted into UKM or any of the eight public universities depend on the students' choice while filling the application form. Every university will receive a list of students from the ministry. This list would have gone through the ministry's selection process and the students are selected based on the projected number of students for each program that has been set by the universities concerned. In other words, the selection criteria for the number of Matriculation and STPM students are under 
the control of the ministry of IHE. However, for diploma students, the universities are given the authority to make their own selection and determine the eligibility of students to be admitted.

\subsection{Research Objectives}

The decline in IHE's mean entrance CGPA is very worrying since it could affect Malaysia's aim to produce top talents who are on par with other developing countries (Hafizah et al., 2011; Norhani et al. 2005). This study aims to investigate FTSM students' ${ }^{6}$ academic achievement based on the number of years of their study and also entry requirements. The questions developed in this study are as follows:

a) Are students able to improve their CGPA while in IHE?

b) Is FTSM receiving low quality students?

c) How do STPM, Matriculation and Diploma students perform while in IHE?

d) Are low achievers in STPM, Matriculation and Diploma able to compete while in IHE?

\section{Research Methodology}

This study uses survey questionnaire to collect data. Samples in this study include 144 students in the $1^{\text {st }}$ year through $3^{\text {rd }}$ year, who are from the 2011/2012 sessions, from Multimedia, Computer Science, Industrial Computing, and Systems Development programs at FTSM.

\section{Results and Discussions}

The results of this study are divided into two sections. The first section is CGPA verses year of study, which would compare students' CGPAs during their 1st, 2nd, and 3rd year in FTSM. It would answer the first and second research questions. The second section of this study compares the current CGPA in IHE of post STPM, Matriculation and Diploma students. This section would answer the third and fourth research questions.

\subsection{CGPA verses Year of Study}

In this study, $41 \%$ (59 students) of the respondents were $1^{\text {st }}$ year students, $28.5 \%$ (41 students) were $2^{\text {nd }}$ year students, while the remaining $30.5 \%$ (44 students) were $3^{\text {rd }}$ year students. In answering the first research question, ANOVA analysis has been used to examine the significant differences among the mean CGPAs of $1^{\text {st }}, 2^{\text {nd }}$ and $3^{\text {rd }}$ year students. The ANOVA test analysis in Table $1 \mathrm{~b}$ shows that there are significant differences in CGPAs among $1^{\text {st }}, 2^{\text {nd }}$ and $3^{\text {rd }}$ year students in FTSM, $[F(2,141)=3.733, p=0.026]$. Scheffe post hoc test in Table $1 \mathrm{c}$ shows that there are significant differences in $2^{\text {nd }}$ year CGPA (mean $=3.0444, \mathrm{sd}=0.4252$ ) compared to students in $3^{\text {rd }}$ year ( mean $\left.=3.2680, \mathrm{sd}=0.2875\right)[\mathrm{p}=0.026]$. Results of this analysis show that students have been able to increase their CGPAs during their $3^{\text {rd }}$ year. The findings of this study are consistent with Hafizah et al. (2011), who found that students' achievement has increased $\left(3^{\text {rd }}\right.$ and $4^{\text {th }}$ year students have better CGPAs than $2^{\text {nd }}$ and $1^{\text {st }}$ year students) in JKEES, UKM.

The ANOVA analysis, which is used to answer the second research question in Table $1 \mathrm{~b}$, shows no significant difference $[F(2,136)=1.130, p=0.326]$ in pre-university CGPA means among 1st, 2 nd, and 3rd year students. This means that FTSM has been receiving similar quality of students; hence the promotion done by FTSM to attract pre-university students with excellent CGPAs has not been effective. In this aspect, the findings of this study differ from that of Hafizah et al. (2011), who found that the mean entrance CGPA in JKEES has declined.

Table 1a. Comparison of mean CGPAs based on year of study

\begin{tabular}{lllll}
\hline & & $\mathrm{N}$ & Mean & $\begin{array}{l}\text { Standard } \\
\text { deviation }\end{array}$ \\
\hline \multirow{4}{*}{ pre_CGPA } & $1^{\text {st }}$ year & 58 & 2.9010 & .40855 \\
& $2^{\text {nd }}$ year & 38 & 2.7761 & .37748 \\
& $3^{\text {rd }}$ year & 43 & 2.8188 & .45485 \\
& Total & 139 & 2.8414 & .41586 \\
& $1^{\text {st }}$ year & 59 & 3.1861 & .40872 \\
FTSM_CGPA & $2^{\text {nd }}$ year & 41 & 3.0444 & .42523 \\
& $3^{\text {rd }}$ year & 44 & 3.2680 & .28753 \\
& Total & 144 & 3.1708 & .38830 \\
\hline
\end{tabular}


Table 1b. ANOVA test: comparison of mean CGPAs based on year of study

\begin{tabular}{lllllll}
\hline & & Sum of squares & df & Mean square & F & Sig \\
\hline \multirow{2}{*}{ pre_CGPA } & Between groups & .390 & 2 & .195 & 1.130 & .326 \\
& Within groups & 23.475 & 136 & .173 & & \\
& Total & 23.865 & 138 & & & \\
& Between groups & 1.084 & 2 & .542 & \multirow{3}{*}{3.733} & .026 \\
FTSM_CGPA & Within groups & 20.477 & 141 & .145 & & \\
& Total & 21.561 & 143 & & & \\
\hline
\end{tabular}

Table 1c. Scheffe post hoc test comparison of mean CGPAs based on year of study

\begin{tabular}{|c|c|c|c|c|c|c|}
\hline \multirow{2}{*}{$\begin{array}{l}\text { Dependent } \\
\text { variable }\end{array}$} & \multirow[t]{2}{*}{ (J) year } & \multirow{2}{*}{$\begin{array}{l}\text { Mean } \\
\text { difference } \\
(\mathrm{I}-\mathrm{J})\end{array}$} & \multirow[t]{2}{*}{ Std error } & \multirow[t]{2}{*}{ Sig } & \multicolumn{2}{|c|}{$95 \%$ Confidence interval } \\
\hline & & & & & Lower bound & Upper bound \\
\hline \multirow{6}{*}{ FTSM_CGPA } & $2^{\text {nd }}$ year & .14171 & .07748 & .191 & -.0500 & .3334 \\
\hline & $3^{\text {rd }}$ year & -.08185 & .07591 & .560 & -.2696 & .1059 \\
\hline & $1^{\text {st }}$ year & -.14171 & .07748 & .191 & -.3334 & .0500 \\
\hline & $3^{\text {rd }}$ year & $-.22356^{*}$ & .08272 & .028 & -.4282 & -.0189 \\
\hline & $1^{\text {st }}$ year & .08185 & .07591 & .560 & -.1059 & .2696 \\
\hline & $2^{\text {nd }}$ year & $.22356^{*}$ & .08272 & .028 & .0189 & .4282 \\
\hline
\end{tabular}

*. The mean difference is significant at 0.05 level.

\subsection{Current CGPA in FTSM verses Pre-University CGPA}

The entry requirement into IHE is having excellent results in STPM, Matriculation or Diploma. The breakdown of respondents according to their type of qualification in entering FTSM is as follows: $52.2 \%$ (70 students) were post-matriculation students, $31.3 \%$ (42 students) were STPM leavers and the remaining $16.4 \%$ (22 students) were Diploma holders. This study examines the academic performance of students with STPM, Matriculation and Diploma while they are in IHE. Descriptive analysis of the mean is used to answer the third research question while the ANOVA tests are used to answer the fourth research question.

\subsubsection{Current CGPA in FTSM Compared to STPM CGPA}

Among the post-STPM students in this study, majority of them had STPM CGPAs between 2.50-2.99 (69\%). Only $16.7 \%$ had CGPAs between 2.00 to 2.49 , while the remaining $14.3 \%$ had STPM CGPAs between 3.00 to 3.49. Descriptive analysis of their mean CGPAs in FTSM in Table 2a shows that post-STPM students have managed to increase their CGPAs while in IHE. Students who entered with STPM CGPAs between 2.00 to 2.49 have managed to increase their mean CGPA to 3.2971 while studying in IHE. Similarly, students who entered with STPM CGPAs of 2.50-2.99 have managed to increase their mean CGPA to 3.4452 while in IHE. Students who entered with STPM CGPAs of 3.00 to 3.49 have managed to secure mean CGPA of 3.5117 while in IHE.

The ANOVA analysis is used to examine the significant differences between the mean of FTSM CGPA of post-STPM students. The result of the ANOVA test in Table $2 b$ shows no significant differences in FTSM CGPAs among students with different levels of STPM CGPAs; $[\mathrm{F}(2,39)=1.798, \mathrm{p}=0.179]$. This means that students with low achievement in STPM are still able to compete with high-achieving students during their study in IHE. This finding is consistent with Hafizah et al. (2011), who found that there is no dependency between students' CGPAs in IHE and their pre-university CGPAs. Hafizah et al. (2011) also found that post-STPM students have been consistent in their entry achievement as well as their graduation achievement.

Table 2a. Comparison of FTSM mean CGPAs based on STPM CGPAs

\begin{tabular}{|c|c|c|c|c|c|}
\hline $\begin{array}{l}\text { STPM } \\
\text { CGPA }\end{array}$ & $\mathrm{N}$ & $\begin{array}{l}\text { Mean } \\
\text { FTSM } \\
\text { CGPA }\end{array}$ & $\begin{array}{l}\text { Standard } \\
\text { deviation }\end{array}$ & Minimum & Maximum \\
\hline $2.00-2.49$ & 7 & 3.2971 & .27287 & 2.80 & 3.65 \\
\hline $2.50-2.99$ & 29 & 3.4452 & .21231 & 2.91 & 3.80 \\
\hline $3.00-3.49$ & 6 & 3.5117 & . 16558 & 3.25 & 3.73 \\
\hline Total & 42 & 3.4300 & .22176 & 2.80 & 3.80 \\
\hline
\end{tabular}


Table 2b. ANOVA test: comparison of mean FTSM CGPAs based on STPM CGPAs

\begin{tabular}{llllll}
\hline & Sum of squares & df & Mean square & F & Sig \\
\hline Between groups & .170 & 2 & .085 & 1.798 & .179 \\
Within groups & 1.846 & 39 & .047 & & \\
Total & 2.016 & 41 & & & \\
\hline
\end{tabular}

\subsubsection{Current CGPA in FTSM Compared to Diploma CGPA}

Among the Diploma holders involved in this study, majority of the respondents had Diploma CGPAs between 3.00 to 3.49 (63.6\%), followed by $31.8 \%$ with Diploma CGPAs between 3.50 to 4.00 , and only a handful, which is $4.5 \%$ who had Diploma CGPAs between 2.50-2.99. Descriptive analysis of their mean CGPA in FTSM in Table 3a shows that only Diploma holders with Diploma CGPA between 2.00 to 2.49 have managed to increase their CGPA while in IHE. Diploma holders with Diploma CGPA between 3.00 to 3.49 and between 3.50 to 4.00 have not been able to maintain their high CGPAs. This means that the achievement of Diploma holders while in IHE has not been consistent. This finding is consistent with Hafizah et al. (2011), who found that Diploma holders have shown a decrease in performance while in IHE compared with their entry CGPAs.

The ANOVA analysis is used to examine the significant differences between the mean of FTSM CGPAs among Diploma holders. Result of the ANOVA test in Table $3 \mathrm{~b}$ shows no significant differences in FTSM CGPAs among students with different levels of Diploma CGPAs; $[\mathrm{F}(2.19)=0.700, \mathrm{p}=0.509]$. This means that low-achieving students during Diploma are still able to compete with high-achieving Diploma holders during their study in IHE. This finding is consistent with Hafizah et al. (2011), who found no dependency between CGPAs in IHE and pre-university CGPAs.

Table 3a. Comparison of FTSM mean CGPAs based on Diploma CGPAs

\begin{tabular}{|c|c|c|c|c|c|}
\hline $\begin{array}{l}\text { Diploma } \\
\text { CGPA }\end{array}$ & $\mathrm{N}$ & $\begin{array}{l}\text { Mean } \\
\text { FTSM } \\
\text { CGPA }\end{array}$ & $\begin{array}{l}\text { Standard } \\
\text { deviation }\end{array}$ & Minimum & Maximum \\
\hline $2.50-2.99$ & 1 & 3.2700 & 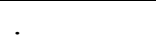 & 3.27 & 3.27 \\
\hline $3.00-3.49$ & 14 & 2.9871 & .44608 & 2.00 & 3.51 \\
\hline $3.50-4.00$ & 7 & 3.1814 & .26511 & 2.78 & 3.49 \\
\hline Total & 22 & 3.0618 & .39219 & 2.00 & 3.51 \\
\hline
\end{tabular}

Table 3b. ANOVA test: comparison of FTSM mean CGPAs based on Diploma CGPAs

\begin{tabular}{llllll}
\hline & Sum of squares & df & Mean square & F & Sig \\
\hline Between groups & .222 & 2 & .111 & .700 & .509 \\
Within groups & 3.009 & 19 & .158 & & \\
Total & 3.230 & 21 & & & \\
\hline
\end{tabular}

\subsubsection{Current CGPA in FTSM Compared to Matriculation CGPA}

Among the post-Matriculation students in this study, majority of them had Matriculation CGPAs between 2.50-2.99 (41.4\%), followed by $31.4 \%$ with Matriculation CGPAs between 2.00 to 2.49 , another $24.3 \%$ had Matriculation CGPA between 3.00 to 3.49 , and only a handful, which is $2.9 \%$ had Matriculation CGPAs between 3.50 to 4.00 . ANOVA analysis is used to examine the significant differences between the mean of FTSM CGPAs among post-Matriculation students. The ANOVA test result in Table $4 \mathrm{~b}$ shows significant differences in FTSM CGPAs among students with different levels of Matriculation CGPAs; $[\mathrm{F}(3,66)=6.624, \mathrm{p}$ $=0.001]$. Scheffe post hoc test in Table 4C shows that only students with Matriculation CGPAs between 3.00 to 3.49 have achieved different CGPAs in FTSM.

The results of this analysis show that students who obtained Matriculation CGPAs between 2.00 to 2.49 had a significant increase in their CGPAs in the IHE (mean $=2.9114, \mathrm{sd}=0.3157$ ). This means that students who have not excelled during their Matriculation are still able to achieve an equivalent CGPA as students with Matriculation CGPAs between 2.50-2.99. However, their CGPAs while in IHE are still not at par with students with Matriculation CGPAs between 3.00 to 3.49 and 3.50 to 4.00. In addition, this study found that students with 
Matriculation CGPAs between 2.50-2.99 have also shown a slight increase in their IHE CGPAs (mean $=3.0059$, $\mathrm{sd}=0.3815$ ). This study also found that students with Matriculation CGPAs between 3.00 to 3.49 and 3.50 to 4.00 are still able to maintain their performance while in IHE. This finding is not consistent with Hafizah et al. (2011), who found that post-Matriculation students have shown a decrease in their IHE CGPAs compared with their entry CGPAs.

Table 4a. Comparison of FTSM mean CGPAs based on Matriculation CGPA

\begin{tabular}{llllll}
\hline $\begin{array}{l}\text { Matriculation } \\
\text { CGPA }\end{array}$ & N & $\begin{array}{l}\text { Mean } \\
\text { FTSM }\end{array}$ & $\begin{array}{l}\text { Standard } \\
\text { deviation }\end{array}$ & Minimum & Maximum \\
\hline $2.00-2.49$ & 22 & 2.9114 & .31573 & 2.23 & 3.47 \\
$2.50-2.99$ & 29 & 3.0059 & .38145 & 2.10 & 3.67 \\
$3.00-3.49$ & 17 & 3.3106 & .23993 & 2.85 & 3.69 \\
$3.50-4.00$ & 2 & 3.5700 & .26870 & 3.38 & 3.76 \\
Total & 70 & 3.0663 & .36746 & 2.10 & 3.76 \\
\hline
\end{tabular}

Table 4b. ANOVA test: comparison of FTSM mean CGPAs based on Matriculation CGPAs

\begin{tabular}{lccccc}
\hline & Sum of squares & df & Mean square & F & Sig \\
\hline Between groups & 2.156 & 3 & .719 & 6.624 & .001 \\
Within groups & 7.161 & 66 & .108 & & \\
Total & 9.317 & 69 & & & \\
\hline
\end{tabular}

Table 4c. Scheffe post hoc test comparison of mean FTSM CGPAs based on Matriculation CGPAs

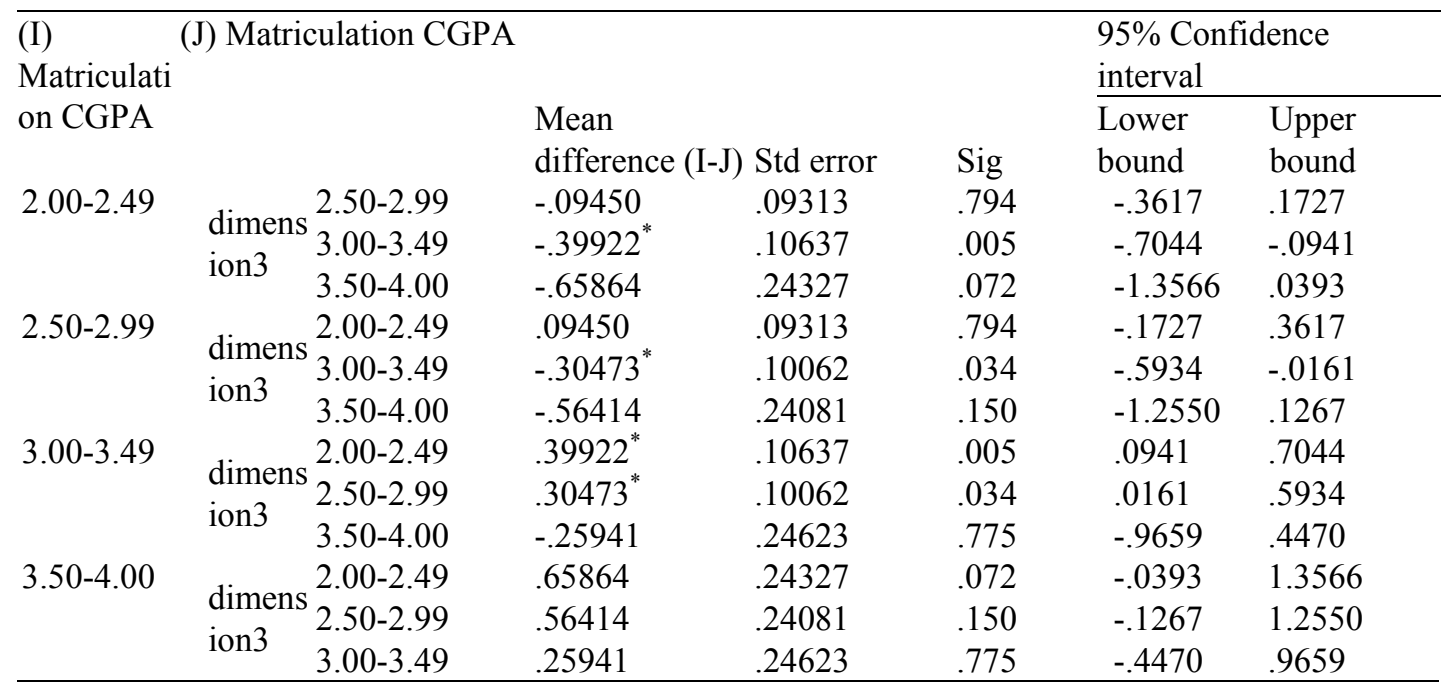

*. The mean difference is significant at 0.05 level.

\section{Discussion and Conclusion}

Selection into institutions of higher learning should not only depend on pre-university CGPAs, but also on knowledge and interest in the selected program since these aspects are also important. This analysis shows that there is no dependency between pre-university CGPAs and students“ performance in institutions of higher learning. Low-entrance CGPA could not be translated to the same low CGPA while in IHE. Students with low pre-university CGPAs are still able to graduate with higher CGPA while in IHE.

Overall, this study shows that there is no difference in the mean of FTSM's entrance CGPA for three consecutive years. This means that FTSM has been enrolling students of the same quality into the faculty. In addition, this study found that FTSM students' academic performance has not declined. All post-STPM students have been able to improve their CGPAs while in IHE. Students with low Matriculation CGPAs have also managed to improve their CGPAs in IHE. Meanwhile, students with outstanding Matriculation CGPAs have been able to 
maintain their CGPAs in IHE. Only Diploma holders have shown a decrease in performance compared with their entrance CGPAs. The decline in achievement of the Diploma Graduates while in IHE should be given serious attention. Some drastic measures need to be considered and implemented in the near future so that the quality of graduates produced by FTSM is able to fulfill the government's transformation plan and the university's vision.

\section{Conclusion}

To be academically successful is not an easy task, especially for students in the Computer Science Faculty. Many barriers and obstacles have to be encountered to achieve that distinction. The results of this analysis point out that Diploma holders have not performed well while in IHE.

These findings might help students, teachers and the IHE's administration to plan and take action. For example, students could use factors such as their past performance to plan their career in the future. Teachers could use these findings to plan on their teaching methods. For example, the teaching method used for Diploma holders (who already had some exposure to certain aspects of the syllabus) may be different compared to students who had practically no exposure. University administration could also use these findings in forming intake policies, in setting up appropriate prerequisite courses, as well as in designing the curriculum or motivational courses which could help improve students' performance.

\section{Acknowledgement}

The author would like to thank UKM for providing the research grant (UKM PTS-2011-046).

\section{References}

Abdul Hamid Hamidon, Salbiah Seliman, Mohd Tajudin Hj. Md. Ninggal, Abd. Wahid Kamarulzaman, Yusuf Ahmad, \& Rosdi Ab. Rahman. (1999). Sistem Penasihatan Akademik Di Universiti Teknologi Malaysia, Skudai, Johor. Skudai, Johor: Universiti Teknologi Malaysia.

Adamson, J., \& Clifford, H. (2000). An appraisal of a-level and university examination results for engineering undergraduates. International Journal of Mechanical Engineering Education, 30(3), 265-279. http://dx.doi.org/10.7227/IJMEE.30.3.8

Alexander, S., Amilo, J., Boyle, R., Clark, M., Daniels, M., Laxer, C., Loose, K., \& Shinners-Kennedy, D. (2003). Case studies in admissions to and early performance in computer science degrees. ACM SIGCSE Bulletin, 35(4), 137-147. http://dx.doi.org/10.1145/960492.960541

Hafizah Husain, Norbahiah Misran, Norhana Arshad, Wan Mimi Diyana Wan Zaki, \& Sarifah Nurhanum Syed Sahuri. (2011). Analisis kuantitatif pencapaian akademik pelajar JKEES. Pascasidang Kongres Pengajaran dan Pembelajaran UKM 2011, 95-103.

Norhani Bakri, Noor Zainab Abd Razak, Hamidah Ab Rahman, \& Aminah Ahmad Khalid. (2005). Punca prestasi pembelajaran yang lemah di kalangan pelajar Fakulti Pengurusan dan Pembangunan Sumber Manusia UTM. Jurnal Teknologi UTM, 43(E), 29-44.

Todd, K. L. (2001). A historical study of the correlation between G.C.E. advanced level grades and the subsequent academic performance of well-qualified students in a University Engineering Department. Mathematics TODAY, 37(5), 152-156.

Zuaini Ishak, Nor Aziah Abdul Manaf, \& Rosliza Mat Zin. (2008). Faktor penentu pelajar matrikulasi dalam subjek perakaunan. MJLI, 5, 99-115. 